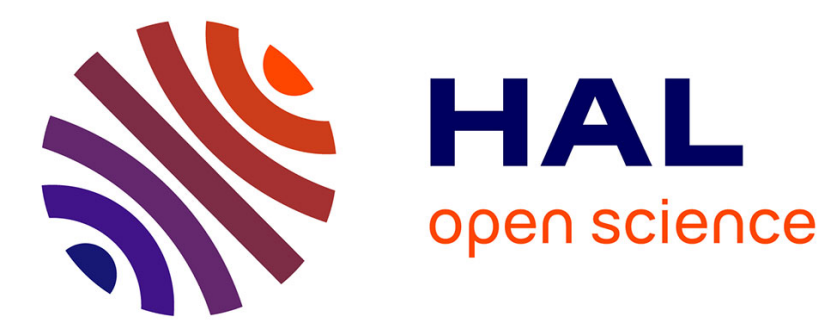

\title{
Development and physiology of the brown alga Ectocarpus siliculosus: two centuries of research
}

Bénédicte Charrier, Susana Coelho, Aude Le Bail, Thierry Tonon, Gurvan

Michel, Philippe Potin, Bernard Kloareg, Catherine Boyen, Akira F Peters, J. Mark Cock

\section{To cite this version:}

Bénédicte Charrier, Susana Coelho, Aude Le Bail, Thierry Tonon, Gurvan Michel, et al.. Development and physiology of the brown alga Ectocarpus siliculosus: two centuries of research. New Phytologist, 2008, 177 (2), pp.319-332. 10.1111/j.1469-8137.2007.02304.x . hal-01806426

\section{HAL Id: hal-01806426 https://hal.science/hal-01806426}

Submitted on 16 Nov 2018

HAL is a multi-disciplinary open access archive for the deposit and dissemination of scientific research documents, whether they are published or not. The documents may come from teaching and research institutions in France or abroad, or from public or private research centers.
L'archive ouverte pluridisciplinaire HAL, est destinée au dépôt et à la diffusion de documents scientifiques de niveau recherche, publiés ou non, émanant des établissements d'enseignement et de recherche français ou étrangers, des laboratoires publics ou privés. 


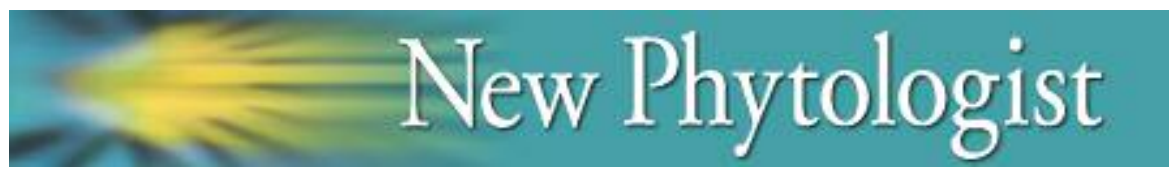

Development and physiology of the brown alga Ectocarpus siliculosus: two centuries of research

\begin{tabular}{|r|l|}
\hline Journal: & New Phytologist \\
\hline Manuscript ID: & NPH-TR-2007-05852.R1 \\
\hline Manuscript Type: & TR - Commissioned Material - Tansley Review \\
\hline Complete List of Authors: & $\begin{array}{l}\text { Charrier, Benedicte; CNRS, Station Biologique } \\
\text { Coelho, Susana; CNRS, Station Biologique } \\
\text { Le Bail, Aude; CNRS, Station Biologique } \\
\text { Tonon, Thierry; CNRS, Station Biologique } \\
\text { Michel, Gurvan; CNRS, Station Biologique } \\
\text { Potin, Philippe; CNRS, Station Biologique } \\
\text { Kloareg, Bernard; CNRS, Station Biologique } \\
\text { Boyen, Catherine; CNRS, Station Biologique } \\
\text { Peters, Akira; CNRS, Station Biologique }\end{array}$ \\
\hline Key Words: & $\begin{array}{l}\text { brown alga , defense, development , Ectocarpus , metabolism, } \\
\text { reproduction, pheophyceae, pheromone }\end{array}$ \\
\hline
\end{tabular}

\section{(4) ScholarONE" \\ Manuscript Central}


1 Development and physiology of the brown alga Ectocarpus siliculosus: two

\section{2 centuries of research}

3

4 Bénédicte Charrier*, Susana M. Coelho, Aude Le Bail, Thierry Tonon, Gurvan Michel, 5 Philippe Potin, Bernard Kloareg, Catherine Boyen, Akira F. Peters, J. Mark Cock.

6

7 UMR7139, Station Biologique, Centre National de la Recherche Scientifique, Université 8 Pierre \& Marie Curie Paris VI, Place Georges Teissier, 29682 Roscoff cedex, France.

9

$10 *$ author for correspondence. Tel :33-2-98-29-23-62 ; fax : 33-2-98-29-23-24; email :

11 charrier@s,s-roscoff.fr

12

13 Nber of figures : 5

14

Word number :

16

17 I- Introduction : 564

18 II - Diversity and taxonomy, distribution and ecology : 708

19 III- Development : 2148

20 IV-Metabolism : 1120

21 V- Interaction with the environment : 1433

22 VI- Conclusion : 277

23 References : 3823

24 Figure legends : 382

25 TOTAL: 10455 


\section{Summary}

2

3 Brown algae share several important features with land plants, such as their photoautotrophic

4 nature and their cellulose-containing wall, but the two groups are distantly related from an

5 evolutionary point of view. The heterokont phylum, to which the brown algae belong, is a

6 eukaryotic crown group that is phylogenetically distinct not only from the green lineage, but

7 also from the red algae and the opisthokont phylum (fungi and animals). As a result of this

8 independent evolutionary history, the brown algae exhibit many novel features and,

9 moreover, have evolved complex multicellular development independently of the other major

10 groups mentioned above. In 2004, a consortium of laboratories, including the Station

11 Biologique in Roscoff and Genoscope, initiated a project to sequence the genome of

12 Ectocarpus siliculosus, a small filamentous brown alga that is found in temperate, coastal

13 environments throughout the globe. The E. siliculosus genome, which is currently being

14 annotated, is expected to be the first completely characterised genome of a multicellular alga.

15 In this review we look back over two centuries of work on this brown alga and highlight the

16 advances that have led to the choice of E. siliculosus as a genomic and genetic model

17 organism for the brown algae.

18

198 words 


\section{Keywords}

2 Brown alga; phaeophyceae; Ectocarpus; development; reproduction; pheromone;

3 metabolism; defense

4

5

6

7

\section{Abbreviations:}

9 ARA, arachidonic acid; BL, blue light; CE: chloroplast envelope; CER: chloroplast 10 endoplasmic reticulum; $\mathrm{Ci}$, inorganic carbon; EPA, eicosapentaenoic acid; DGDG, 11 digalastosyldiacylglycerol; DPG, diphosphatidylglycerol; $\quad$ DGTA, 12 diacylglycerylhydroxymethyl- $N, N, N$-trimethyl- $\beta$-alanine; $\quad$ DGTS, 13 diacylglyceryltrimethylhomoserine; MGDG, monogalactosyldiacylglycerol; PC, 14 phosphatidylcholine; PE, phosphatidylethanolamine; PI, phosphatidylinositol; PG, 15 phospahtidylglycerol; SQGD, sulfoquinovosyldiacylglycerol. 


\section{I- Introduction}

(n)

The brown algae belong to the division Heterokonta and are therefore only very distantly related to the three most intensely studied eukaryotic groups, the animals, fungi and green plants (Baldauf, 2003; Davis, 2004; Fig. 1a). This independent evolutionary history has furnished brown algae with many novel metabolic, physiological, cellular and ecological characteristics including a complex halogen metabolism, cell walls containing many unusual polysaccharides and high resistance to osmotic stress. Developmental processes are particularly interesting in this group, which evolved complex multicellularity independently of the three other major groups listed above. From a more applied point of view, the evolutionary history of the brown algae also underlies the high commercial value of several members of the group in the sense that they have evolved novel biomolecules such as polysaccharides and defence elicitors that have a wide range of applications in industry (Klarzynski et al., 2000; McHugh, 2003).

It is important to note, however, that whilst the independent evolutionary history of the brown algae is the source of much of the interest of this group, it can also be seen as a handicap because the well-developed model organisms from the plant and animal lineages are of limited relevance to brown algal biology. Specialised brown algal models have been developed in specific domains, for example members of the fucoids for cell biology approaches (see references in Corellou et al., 2005), but a polyvalent model organism that allows access to a wide range of questions at the molecular level has been lacking. This situation is changing with the development of genomic and genetic tools for the filamentous brown alga Ectocarpus siliculosus. The sequencing of the genome of this alga has recently been completed and the sequence is currently being annotated 
1 (http://www.cns.fr/externe/English/Projets/Projet_KY/organisme_KY.html). It is therefore an

2 opportune moment to look back at the emergence of Ectocarpus as a model organism.

3 Research on Ectocarpus began in the $19^{\text {th }}$ century with descriptions of species and 4 taxonomy, followed by studies aimed at unravelling reproduction and life history. Other 5 major aspects that have been studied include the sexual pheromones and infection of 6 Ectocarpus by viruses. Research has also been carried out on ultrastructure, photosynthesis 7 and carbon uptake, gamete recognition and resistance to anti-fouling agents. Several 8 eukaryotic parasites of Ectocarpus have been described. A proposition to adopt Ectocarpus as 9 a general model organism for the brown algae was made in 2004 (Peters et al., 2004a). This 10 proposition was based partly on this alga's long history as an experimental organism but also 11 took into account several features that make Ectocarpus an interesting model for genetic and 12 genomic approaches. These features include its small size, the fact that the entire life cycle can be completed in Petri dishes in the laboratory (Müller et al., 1998), its high fertility and rapid growth (the life cycle can be completed in 3 months), the ease with which genetic crosses can be carried out and the relatively small size of the genome (200 Mbp compared with 1095 and $640 \mathrm{Mbp}$ for Fucus serratus and Laminaria digitata respectively; Le Gall et al., 1993 and Peters et al., 2004a).

18 Here we present an overview of the work that has been carried out on Ectocarpus over the last two centuries and discuss how the availability of a number of genomic tools, in particular the complete genome sequence, is expected to accelerate research in many domains of brown 21 algal biology in the coming years. 


\section{II- Diversity and taxonomy, distribution and ecology}

\section{1 - Diversity and taxonomy}

Dillwyn (1802-1809) published the first valid description of Ectocarpus (using the name Conferva siliculosa) based on material collected by W.J. Hooker on "rocks in the sea at Cromer and Hastings". These English localities lie in Norfolk and East Sussex, respectively. Type material, collected by Hooker in 1807, is housed at BM (BM000685585 and BM000685588) under the name C. confervoides. Lyngbye (1819) described the genus Ectocarpus based on material from Denmark and cited C. siliculosa Dillwyn as basionym. The correct nomenclature, therefore, is E. siliculosus (Dillwyn) Lyngbye (see Silva et al., 1996 for further details). E. siliculosus is the type species of the order Ectocarpales which includes most of the smaller brown algae. Originally regarded as phylogenetically primitive, molecular systematics has shown the Ectocarpales to belong to a group of brown algal orders that evolved rather recently. They are closely related to the large and highly differentiated Laminariales which are major components of coastal marine floras (Rousseau \& de Reviers, 1999; Draisma et al., 2003; Cho et al., 2004; Kawai et al., 2007, Fig. 1b). Many species have been described in Ectocarpus (www.algaebase.org, April 2007, lists 392 taxa of Ectocarpus of whom 98 are flagged as "current"; numerous strains publicly available at the Culture Collection of Algae and Protozoa (CCAP) in Oban, U-K, Gachon et al., 2007a). However, only E. fasciculatus Harvey (1841) is currently recognized as a second well-defined species, based on morphology (Russell 1966, 1967a), crossing studies and sequence analyses (StacheCrain et al., 1997). Crossing experiments have shown that the taxon E. siliculosus may represent a species complex (Stache-Crain et al., 1997) and ongoing, refined analyses are expected to resolve this complex, increasing the number of recognised species. Identification of different species of Ectocarpus based on morphology is difficult due to the plasticity of the commonly examined features (habit, branching pattern, size of sporangia). In addition, the 
1 two generations of a species may differ considerably (Müller, 1972a; Kornmann \& Sahling, 2 1977).

\section{2 - Distribution}

E. siliculosus is distributed world-wide in temperate regions, but does not occur in the tropics and south of the Antarctic convergence (Stache, 1990; Wiencke \& Clayton, 2002). It occurs in fully marine and in low-salinity habitats (e.g. 5 psu in Finland) and has even been recorded at a fresh-water site in Australia (West \& Craft, 1996) and in a salt polluted river in Germany (Geissler, 1983). Records of E. fasciculatus are mainly from the North Atlantic but there are some from Korea, Chile, South Georgia and South Africa (www.algaebase.org, 2007). On the shore, Ectocarpus occurs from high inter-tidal pools to the sub-littoral. It is found on abiotic substrata (rocks, wood, plastic, ship hulls) and epiphytic on macrophytes or free-floating (Russell, 1967a,b; 1983a,b). As a result of its ability to grow on a range of abiotic substrates, Ectocarpus is a common fouling alga (Morris \& Russell, 1974).

There have been a limited number of ecophysiological and ecological studies in Ectocarpus.

18 Growth rate is dependent on temperature, and there is evidence that temperature also 19 influences the life cycle, at least in some strains (Müller, 1963; Bolton, 1983; see the "sporophyte and gametophyte architecture" section). The thermo-sensitivity of different 21 strains suggests that there is a genetic heterogeneity within the Ectocarpus genus (Bolton, 1983). A similar result was obtained for osmo-acclimation (Thomas \& Kirst, 1991a,b; see the "Abiotic stress" section). In the field, Ectocarpus is a short-lived annual which may dominate the ectocarpoid flora on kelps (Russell, 1983a,b). Despite the commonness of Ectocarpus, 
1 there are few data concerning phenology in the field (mostly to be extracted from floristic

2 works) and nothing precise on seasonality or habitats of the two generations.

3 The availability of the E. siliculosus genome sequence is expected to facilitate the analysis

4 of the ecology of this species by providing a basis for the development of molecular markers.

5 Particularly important challenges in this respect will include the identification of the sex locus

6 and of genes specifically expressed in the two generations, as these will provide molecular

7 tools that can be used to investigate several aspects of the life cycle under field conditions.

8 Molecular markers will also allow the exploration of genetic polymorphism amongst

9 Ectocarpus species from multiple locations across the globe.

\section{III- Development}

\section{1 - Life cycle and reproduction}

Male and female gametes are morphologically identical in Ectocarpus (isogamy) but differ with respect to their physiology and their behaviour: female gametes settle sooner and produce a pheromone whilst male gametes swim for longer and are attracted to the pheromone produced by the female. Studies on the reproduction of Ectocarpus began with the observation of sexual fusions involving the attraction of male gametes to settled female gametes from field thalli of E. siliculosus at Naples, Italy (Berthold, 1881). These findings were hotly debated until Sauvageau (1896, 1897) and Oltmanns (1899) succeeded in repeating the experiment. Gamete fusions in Ectocarpus were later used by Hartmann (1934) to support his erroneous theory of relative sexuality (see Müller, 1976a for details). Knight (1929) identified the young, unilocular sporangium as the site of meiosis, Papenfuss (1935) and Kornmann (1956) published major contributions to the life history of Ectocarpus, and 
1 Boalch (1961) developed refined culture techniques. The entire life history of E. siliculosus

2 from Naples was finally unravelled by Müller (1964, 1966, 1967, 1972b) using clonal cultures

3 and chromosome counts. It is schematised in Fig. 2. The basic life history of E. siliculosus

4 involves an alternation between the sporophyte and dioecious gametophytes, and sex

5 determination is genotypic (Müller, 1967). Male and female gametophytes are

6 morphologically indistinguishable. One of the problems for understanding the life history was

7 that sporophytes and gametophytes are difficult to distinguish morphologically. Another

8 problem was that zoids from plurilocular reproductive organs have different functions

9 according to the generation forming them: on sporophytes they contain asexual zoospores that

10 directly reproduce the sporophyte, on gametophytes they contain gametes. Further

11 complications include the parthenogenesis of unfused gametes, which develop into haploid

12 parthenogenetic sporophytes morphologically indistinguishable from diploid sporophytes, and

13 heteroblasty (different fates) of spores from unilocular sporangia, developing either into

14 gametophytes or into sporophytes. Furthermore, life cycle generation is not determined

15 rigidly by ploidy (Müller, 1967).

16 An important challenge for the future will be the characterisation of the genetic mechanisms

17 that control life cycle progression in Ectocarpus. This will require the development of 18 methodologies for positional cloning of mutated loci and of genome-wide methods to analyse

19 gene expression throughout the life cycle. Work is currently ongoing in several groups to

20 develop these techniques.

\section{2 - Sporophyte and gametophyte architecture}

E. siliculosus is a small filamentous alga that grows to about $30 \mathrm{~cm}$ in length in nature, but

24 it may become fertile in the laboratory at $1-3 \mathrm{~cm}$. 
1 Sporophyte development is initiated with the germination of the zygote. The first division

2 produces two cells of identical developmental fate (Peters et al., 2004b). Subsequent mitoses

3 lead to the formation of a basal (or prostrate) filamentous structure, defining the early

4 sporophyte (Fig. 3a). Phaeophycean hairs, i.e. hyaline filaments devoid of plastids developing

5 from a basal meristem, are absent in Ectocarpus but present in the sister genus Kuckuckia.

6 However, in Ectocarpus the distal end of filaments, or of plurilocular sporangia, may be less

7 pigmented and resemble a hair; such structures may be referred to as pseudo-hairs (Cardinal,

8 1964; Pedersen, 1989). If the growth conditions are favourable (Ravanko, 1970), erect

9 filaments (called "upright" filaments) emerge after a few days, contributing to the

10 establishment of an overall filamentous architecture (Fig. 3c).

11 The typical structure of a vegetative cell is illustrated in Fig. 4. Features common to all

12 brown algal cells include a chloroplast surrounded by four membranes, arranged as two

13 double-membraned envelopes (chloroplast envelope, CE). The second envelope is loosely

14 associated with the chloroplast and forms part of the chloroplast endoplasmic reticulum

15 (CER). The lamellae of the chloroplast are composed of three thylakoids, which are absent

16 from the pyrenoid space (Bouck, 1965; Oliveira \& Bisalputra, 1973). In Ectocarpus the

17 chloroplast is ribbon-shaped. The size and number of chloroplasts may vary within the same organism (Ravanko, 1970). Other typical features of Ectocarpus include several prominent and pedunculated pyrenoids on the inner face of the chloroplast, which are used as a taxonomic marker for the Ectocarpales (Evans, 1966; Rousseau \& de Reviers 1999). CER and

21 CE envelopes also surround pyrenoids, this time being tightly adjacent. A third external 22 envelope, called the pyrenoid sac, surrounds the pyrenoid but has no connection with the 23 reticulum system (Bouck, 1965). The nuclear envelope is continuous with the CER, which, 24 itself is in close vicinity to the Golgi apparatus (Bouck, 1965; Oliveira \& Bisalputra, 1973). It 25 has been hypothesised that these connections create a complex network of membranes 
1 allowing photosynthates to be efficiently transferred from the chloroplast to the Golgi

2 apparatus, the latter being also in direct contact with the CER (Oliveira \& Bisalputra, 1973).

3 Cytoplasmic ER is dispersed throughout the cytoplasm and is mainly rough (Oliveira \& 4 Bisalputra, 1973). Osmiophilic bodies (OSB) which are thought to contain lipids, are 5 dispersed throughout the cytoplasm and probably originate from the CER (Oliveira \& 6 Bisalputra, 1973). They have been observed within the cell wall, and also external to it.

7 Vacuoles can be either large structures occupying peripheral locations (Oliveira \& Bisalputra,

8 1973) in fixed material, or most of the cellular space (as in land plant cells; Knight, 1929,

9 confirmed by data from our laboratory, after staining with cresyl blue or neutral red, on 10 sporophytic filaments). The nuclear region encompasses two centrioles, which are considered 11 as a microtubule organising centre (MTOC; Katsaros et al., 1991). The chromosome number 12 in the haploid nucleus is estimated to be ca 25 (Peters et al., 2004a). Mitochondria are preferentially peripherally located. They are maternally inherited (Peters et al., 2004b). The cell wall consists of a fibrillar matrix (see the "Photosynthesis and carbohydrate metabolism" section) with several plasmodesmata distributed uniformly along the cross walls. Upon ageing, cell wall ingrowths occur, accompanied by a reduction in the size of the nucleus, mitochondria, ER and Golgi, followed by the disintegration of the chloroplasts and finally by autolysis of the cytoplasm (Oliveira \& Bisalputra, 1977a,b).

Most of the reproductive organs are carried by upright filaments (Müller, 1964). Two types of reproductive organs are produced by the sporophyte: plurilocular and unilocular sporangia. Plurilocular sporangia are cone-shaped three-dimensional structures of variable size (Knight, 1929), composed of a large number of locules with different shapes (Baker \& Evans, 1973b; Fig. 3e). These locules are generated by several successive mitoses and each gives rise to a single zoospore, which is released through the apex of the sporangium. The mito-spores, 
1 which are bi-flagellate and competent for swimming shortly after their release (Müller, 1980),

2 are a means of vegetative reproduction. Unilocular sporangia are born on the side of branches

3 (Fig. 3f, Baker \& Evans, 1973a). A single meiosis occurs within the single thick-walled locule

4 (Baker \& Evans, 1973a) and this is followed by several mitoses, which generate about a

5 hundred meio-spores, half of which are female and half male (Müller, 1980). Müller (1963)

6 and Ravanko (1970) reported that plurilocular sporangia were produced when the external

7 temperature was relatively high $\left(\sim 20^{\circ} \mathrm{C}\right.$ or summer), whereas unilocular sporangia were

8 produced when the temperature was lowered to $13^{\circ} \mathrm{C}$ (mimicking winter conditions).

9 However, this temperature dependence is not observed in many strains of Ectocarpus (A.F.

10 Peters, unpublished results). Meio-spores germinate to produce haploid, dioecious

11 gametophytes (Fig. 3b,d). These are filamentous organisms similar to the sporophyte, but with

12 two important differences. Firstly, the meio-spore germinates asymmetrically to produce a

13 rhizoid and an upright filament, so no prostrate structure forms (A.F. Peters, unpublished

14 results). Secondly, the thallus is more ramified than that of the sporophyte (Müller, 1980).

15 Gametophytes produce only plurilocular gametangia and these are similar structurally to

16 plurilocular sporangia on sporophytes. Gametes resemble mito-spores in terms of their size

17 and motility.

18 The developmental patterning varies greatly across the Ectocarpus species complex and is also dependent on the environment, growth conditions and even the age of the algae for some features (Ravanko, 1970). This plasticity is observed for the branching frequency and the

21 number, shape, structure and positioning of the reproductive organs on filaments (Knight, 1929; Müller, 1980; Kim \& Lee, 1992). Phytohormones, especially cytokinins, have also been reported to influence the development of Ectocarpus sporophytes (Pedersén, 1968, 1973). 
1 As mentioned above, brown algae are interesting for developmental studies because they

2 have independently evolved complex multicellularity. Ectocarpus is a relevant model to

3 address this problem as it is closely related to complex algae such as the Laminariales and the

4 Fucales. However, developmental processes in Ectocarpus are clearly simplified compared

5 with its morphogenetically more complex sister families, which provides an advantage for the

6 detailed dissection of these developmental processes. In particular the simple growth pattern

7 of the uniseriate, branched filaments represents an ideal system for the combined application

8 of genetic and mathematical modelling approaches to understanding developmental patterning

9 and then addressing the issue of the evolution of development and multicellularity.

\section{3 - Gametes and spores}

Several electron microscopy studies of the motile cells (zoids) of Ectocarpus have been reported (Baker \& Evans 1973a,b; Lofthouse \& Capon, 1975; Maier, 1997a,b). The typical structure of an Ectocarpus zoid is illustrated fig. 5.

Ectocarpus zoids correspond to the "primitive" type of brown algal zoid according to Kawai (1992). Gametes and spores typically contain a single chloroplast with a pyrenoid (Baker \& Evans, 1973a; Lofthouse \& Clayton, 1975; Maier, 1997a). As in the vegetative cells, lamella are composed of three thylakoids and the nuclear envelope is in continuity with the chloroplast endoplasmic reticulum (Maier, 1997a). The nucleus of the male gamete is rich in heterochromatin. Several dictyosomes are present in gametes and spores (Baker \& Evans, 21 1973b; Maier, 1997a). The Golgi apparatus of mito-spores is very active both before and after release (Baker \& Evans, 1973b). This secretory activity may have important functions in the

23 biosynthesis of the adhesive required for gamete adhesion and for the synthesis of new cell wall compounds during germination. 
Ectocarpus gametes and spores are characterized by two flagella with lateral insertion. One

2 is oriented forward and equipped with mastigonemes (hairs), and propels the cell with

3 meandering beats. The second is oriented obliquely backwards, and has no mastigonemes.

4 Most of the time this posterior flagella is passively dragged but occasional lateral beats induce

5 abrupt changes in direction of up to $180^{\circ}$ (Geller \& Müller, 1981). Gametes and spores have a

6 concave depression at the level of the eyespot into which the swelling of the proximal part of

7 the posterior flagellum fits (Baker \& Evans, 1973b; Kreimer et al., 1991; Maier, 1997a). The

8 possible function of the eyespot is to reflect and focus incident light onto the site of

9 photoreception (Kawai et al., 1990; Kreimer et al., 1991). Zoids are capable of positive

10 phototaxis and their posterior flagellum shows strong autofluorescence when irradiated by

11 blue light $(450 \mathrm{~nm})$. The photoreceptor pigment is a flavoprotein, which is periodically

12 shaded by a carotenoid stigma (Müller et al., 1987; Kawai, 1988). The acronema (the

13 whiplash tip) is extremely sensitive to mechanical stress and plays an important role in

14 establishing the initial sexual contact between gametes. The details of the flagellar apparatus

15 of both female and male gametes have been studied by electron microscopy (Müller \& Falk,

16 1973; Maier, 1997b). Despite their different behaviours, no difference in their fine structure

17 has been detected (Müller \& Falk, 1973).

18 The pheromone that attracts male gametes to female gametes is an unsaturated hydrocarbon.

19 The substance initially identified was ectocarpene (all-cis-1-(cycloheptadiene-2',5'-yl)-

20 butene-1) (Müller et al., 1971; Müller, 1976b; Müller, 1978; Müller \& Schmid, 1988) but

21 more recently Boland et al. (1995) have shown that a thermally labile cyclopropyl precursor,

22 pre-ectocarpene, is more active by three orders of magnitude and is thus the actual 23 pheromone.

24 There is evidence that cell-to-cell recognition between Ectocarpus gametes is mediated by

$25 \mathrm{~N}$-acetyl glucosamine residues exposed on the plasma membrane of the female gametes and 
1 that these residues are specifically recognized by a receptor on the male gamete (Schmid, 2 1993; Schmid et al., 1994a). In addition, the lectins concanavalin A (Con A) and Aleuria aurantia agglutinin (AAA) bind specifically to the anterior flagella of Ectocarpus gametes

4 and the molecules with which they interact also may be involved in the gamete recognition 5 process (Maier \& Schmid, 1995).

6 Zoids from plurilocular and unilocular Ectocarpus sporangia share similar overall 7 intracellular structures, but there are some important differences: plurilocular zoids are smaller and swim faster with more rapid changes of direction (Baker \& Evans, 1973a). Zoids from unilocular sporangia are strikingly different from the other Ectocarpus cell types (both 10 plurilocular zoids and vegetative cells) in that the nucleus is physically separated from the 11 chloroplast. Moreover, secretory activity is lower than in zoids from plurilocular sporangia (Baker \& Evans, 1973b).

13 Gametes of Ectocarpus have also been used to study chemotaxis (Boland et al., 1983), receptor modelling (Boland et al., 1989) and phototaxis (Kawai et al., 1990; Kreimer et al., 1991). Protocols for isolation and biochemical characterisation of plasma membrane and CER membrane have also been developed (Schmid et al., 1992). Together with more recently developed molecular tools, these methods now offer access to a range of interesting biochemical events that take place during gamete interaction at fertilization such as chemoreception, cell-cell recognition and fusion processes.

IV- Metabolism 
Marine environment constrains several aspects of photosynthesis in brown algae. First,

2 carbon dioxide is not the main source of inorganic carbon (Ci). Indeed, seawater in

3 equilibrium with air contains only $13 \mu \mathrm{M} \mathrm{CO}_{2}$, but more than $2 \mathrm{mM}$ anionic carbon, mainly in

4 the form of $\mathrm{HCO}_{3}{ }^{-}$(Beer, 1994). Secondly, when seaweeds are immersed they do not receive

5 the full light spectrum. Light absorption increases with water depth and varies according to

6 the wavelength: red-light $(650 \mathrm{~nm})$ is first absorbed followed by purple $(400 \mathrm{~nm})$ and yellow-

$7 \quad(550 \mathrm{~nm})$ lights. In contrast green $(500 \mathrm{~nm})$ and blue $(450 \mathrm{~nm})$ lights display a strong

8 penetration: at $10 \mathrm{~m}$ depth red light is almost fully absorbed whereas the absorption of green-

9 and blue lights is not significant.

Adapted to these conditions, brown algae differ from land plants by the pigment 11 composition of their light harvesting complexes (LHCs). Chlorophyll c (chl c) and the carotenoid fucoxanthin are indeed the main light-haversting pigments of brown algae. Their presence broadens the absorption spectrum toward the green light relative to the chlorophytes.

14 Brown algae features two different LHCs associated to photosystems I and II (PSI and PSII), but their pigment composition is controversial. Barrett and Anderson (1980) described a fucoxanthin-chl a/c protein and a violaxanthin enriched-chl a/c protein. Conversely Alberte $e t$ al. (1981) reported a chl a/c protein devoid of fucoxanthin and a second LHC containing chl a and fucoxanthin but not chlorophyll c. More recent analyses showed that the LHCs associated to PSI and PSII are in fact virtually identical with respect to their pigmentation and peptide composition. All complexes bound chl a, chl c and fucoxanthin in the proportion $6: 2: 7$, but the LHC associated to PSI is significantly enriched in violaxanthin (De Martino et al., 2000). As in plants, these accessory pigments transfer energy to chlorophyll a within the photosynthetic reaction centres (Grossman et al., 1995). Violaxantin does not participate in

24 light harvesting but is involved in photoprotection (Demmig-Adams \& Adams, 1992; 
2 Under saturating red light, photosynthesis of E. siliculosus follows a circadian rhythm

3 with maxima at about noon and can be stimulated by a pulse of blue light (BL) (Schmid \&

4 Dring, 1992). This stimulation is also observed in other Phaeophytes, but mostly absent in 5 green or red algae (Schmid et al., 1994b). BL induces several responses: an acidification at 6 the surface of E. siliculosus (Schmid \& Dring, 1993), accompanied by bicarbonate uptake 7 (Schmid, 1998). A plasma membrane $\mathrm{H}^{+}$-ATPase is thought to be activated, and the resulting acidification to increase the conversion of $\mathrm{HCO}_{3}{ }^{-}$to $\mathrm{CO}_{2}$ in the extracellular space (Schmid \& Dring, 1993). Recently, such BL-induced $\mathrm{H}^{+}$-ATPases have been identified in the brown alga Laminaria digitata (Klenell et al., 2002). BL also triggers the mobilization of an internal carbon source, since photosynthesis is stimulated even in the absence of external $\mathrm{Ci}$ (Schmid \& Dring, 1996). As a result, a C4-like metabolism was initially proposed to exist in $E$. siliculosus (Schmid \& Dring, 1996) but not all the enzymes necessary for a C4 cycle were detected (Bush \& Schmid, 2001) and the pool of intermediates seems to be too small to act as an organic carbon stock (Hillrichs \& Schmid, 2001). The sequestration of a pool of inorganic carbon in the vacuole and its movement to the cytosol in response to BL is now the favoured hypothesis (Schmid \& Hillrichs, 2001). Analysis of the sequence of the E. siliculosus genome will help to confirm whether or not a $\mathrm{C} 4$ pathway exists in the brown algae.

In contrast to the Plantae (Moreira et al., 2000), the Phaeophyceae do not store the carbon assimilated by photosynthesis as insoluble starch granules, but instead as the soluble 1,3- $\beta$ 21 glucan polymer (laminarin) localised in the cytosol (Craigie, 1974), and as mannitol, involved in osmo-acclimation (Davis et al., 2003; see the "Abiotic stresses" section). Brown algae also produce complex polysaccharides which constitute their cell wall. They synthesize some neutral polysaccharides in common with land plants, such as cellulose (Carpita \& McCann, 2000), but also unique anionic polysaccharides, such as alginates and sulphated fucans 
1 (Kloareg \& Quatrano, 1988). Ectocarpus has not been well studied in this respect, but

2 preliminary analyses in our laboratory confirm that all of the polysaccharides typical of brown

3 algae are present in this genus (Estelle Deniaud, pers. comm.). The biosynthetic pathways of

4 these brown algal polysaccharides are essentially unknown and the genome of E. siliculosus

$5 \quad$ will be a much anticipated asset to investigate these crucial metabolisms.

\section{2- Lipid metabolism}

8 Worldwide, at least 50 species of brown algae are used as human food. Their lipid content has therefore attracted considerable attention from the viewpoint of both nutrition and pharmacology. A number of studies have been conducted to profile and quantify the fatty

11 acids and the different classes of lipids in these organisms, and to investigate whether the various lipid patterns correlate with the taxonomic position or any other characteristic of the brown algae. Brown algal polar lipids include several common glycolipids (MGDG, DGDG, SQGD, see list of abbreviations) and phospholipids (PC, PE, PI, PG and DPG). Interestingly, several reports have highlighted the high proportion of long chain polyunsaturated fatty acids (LC-PUFAs) (Eichenberger et al., 1993). Moreover, most of the Phaeophyceae contain the

17 betaine lipids DGTA and DGTS, and either contain the common phosphatidylcholine 18 phospholipids in surprising low amounts or do not produce them at all (Eichenberger et al., 1993). All Ectocarpales contain phosphatidylcholine, but exhibit interspecific variation in their DGTA content: E. fasciculatus strains contain this lipid while E. siliculosus strains do not (Müller \& Eichenberger, 1995; Müller, 1995). DGTA may therefore be used as a taxonomic marker (Müller, 1995), although an E. fasciculatus strain deficient in DGTA

23 biosynthesis has been described. Genetic analysis of such a strain identified an autosomal locus necessary for the biosynthesis of this lipid (Müller \& Eichenberger, 1997). 
1 A novel phosphoglyceride, designated PX, was first isolated from E. siliculosus. It was

2 shown to account for $2-4 \%$ of total lipids (Schmid et al., 1994c), and to accumulate mostly in

3 the plasma membrane of gametes. Since PX is rich in 20:4n-6 (ARA) and 20:5n-3 (EPA), it

4 has been suggested that it could represent a potential reservoir for pheromone precursors. PX

5 was subsequently detected in other brown algae (Ectocarpales, Fucales and Sphacelariales;

6 Schmid et al., 1994c).

7 Lipid metabolism plays also major roles in the control of defense mechanisms. Therefore, together with the genome sequence, it is likely that the efforts to screen mutants with altered resistance to pathogen attacks, will lead to the phenotyping of plants impaired in lipid or fatty acid metabolic pathways, thereby potentially revealing novel specific traits of this metabolism 11 in brown algae.

\section{V- Interactions with the environment}

\section{1- Ectocarpus pathogens}

Despite of their small size and ephemeral life stages, filamentous brown algae have been frequently reported to be plagued by various pathogens, including viruses (Müller et al., 1998) and eukaryotic parasites of different phylogenetic lineages: oomycetes, chytrids and hyphochytrids (Andrews 1976; Küpper \& Müller 1999; Müller et al. 1999) and by parasites related to the Plasmodiophorea (Karling, 1944; Maier et al., 2000). In addition, numerous historical records described ectocarpoids with abnormal sporangia or vegetative cells suspected to contain unknown parasites (Rattray, 1885; Müller et al., 1998).

24 The oomycete Eurychasma dicksonii has been described mainly in wild populations of 
1 various brown algae including Ectocarpus (Müller et al., 1999) in which it was initially

2 described by Wright (1879). There is a current effort to set up a defined pathosystem using $E$.

3 siliculosus and E. dicksonii, and Ectocarpus strains have been shown to exhibit differential

4 susceptibility to a defined Eurychasma strain. Conversely, several Eurychasma strains exhibit

5 different host specificities, suggesting co-evolution of the two species (Gachon et al., 2007b).

6 The molecular bases of resistance and virulence are under investigation.

7 Chytrids were described earlier by Petersen (1905) and the hyphochytrid Anisolpidium 8 ectocarpii was described by Karling (1943) and Johnson (1957). Like E. dicksonii, 9 Chytridium polysiphoniae (Chytridiomycota) is ubiquitous and can infect many hosts, 10 including E. siliculosus and E. fasciculatus (Müller et al., 1999). Interestingly, its negative 11 effects on photosynthesis of its host was described at the cellular level in the related 12 ectocarpoid $P$. littoralis using fluorescence kinetic microscopy (Gachon et al., 2006). Recently, the 18S rRNA genes of Chytridium polysiphoniae and Eurychasma dicksonii were 14 sequenced and used to clarify their phylogenetic affiliations (Küpper et al., 2006). The plasmodiophorean Maullinia ectocarpii is an obligate intracellular parasite of Ectocarpus spp. 16 (Maier et al., 2000). However, the extent to which this infection occurs in nature and its effect 17 on algal fitness are presently unknown.

18 Viral infections represent by far the most studied phenomenon in E. siliculosus (Müller, 1996; Müller \& Knippers, 2001). Until the late eighties most reports of virus infections in brown algal tissues were based on electron microscopy studies, which sporadically described 21 "virus-like particules" (VLP). Viruses were obtained in culture for the first time from a New 22 Zealand strain of E. siliculosus after lysis of host cells allowing evaluation of their infection potential (Müller et al., 1990; Müller, 1991). Virus infections were found in about 50\% of the individuals of a given natural population (Dixon et al., 2000; Müller et al., 2000) and were 
1 shown to occur worldwide in correlation with the cosmopolitan distribution of E. siliculosus

2 (Müller, 1991; Sengco et al., 1996).

3 The viruses that infect different ectocarpoid algae exhibit considerable variability in size

4 and diameter and, in general, they display a high level of host specificity (Müller et al., 1998).

5 However, several instances of trans-specific infection have been described, for example

6 between EsV-1 (Ectocarpus siliculosus virus-1) and Kuckuckia kylinii (Müller, 1992; Müller

7 \& Schmid, 1996) and also between EfasV-1 (Ectocarpus fasiculatus virus-1) and E.

8 siliculosus (Müller et al., 1996; Sengco et al., 1996). Interestingly, EsV-1 and EfasV-1 are the

9 most similar of the brown algal viruses in terms of their genome size (Müller et al., 1996).

10 The EsV-1 virus specifically infects the single-celled gametes or spores, i.e. the only cells in 11 the life history that lack a cell wall (Maier \& Müller, 1998). Following infection, a single 12 copy of the viral DNA appears to integrate into the host genome (Delaroque et al., 1999). The viral DNA is then transmitted, via mitotic divisions, to all the cells of the developing alga. This has been confirmed by regenerating algae from protoplasts derived from virus-infected gametophytes (Kuhlenkamp \& Müller, 1994). Despite the fact that they carry the integrated 16 virus, vegetative cells do not produce viral particles (Müller et al., 1998). Viral particles are only produced in reproductive organs (sporangia and gametangia) of mature algae from where 18 they are released to infect a new generation of zoids. In addition to these cycles of re19 infection, the viral genome can be also transmitted to progeny through meiosis, in which case it segregates as a Mendelian factor and is inherited by half of the progeny (Müller, 1991;

21 Bräutigam et al., 1995). The pathogenic character of viral infections has been unambiguously 22 confirmed, but this association's main impact is on reproductive success. Plant sterility varies 23 from partial (Müller et al., 1990) to total (Müller \& Frenzer, 1993) but no significant 24 difference in photosynthesis, respiration and growth rate were observed in infected 
1 gametophytes or sporophytes (Del Campo et al., 1997). This contrasts with the reduced

2 photosynthetic performance of Feldmannia species infected with FsV (Robledo et al., 1994).

3 The EsV-1 genome is a circular DNA molecule of a relatively large size (335 Kbp) for a

4 phycodnavirus (Van Etten \& Meints, 1999; Van Etten et al., 2002) with double-stranded

5 regions interrupted by single-stranded regions (Lanka et al., 1993; Klein et al., 1994). Both

$6 \quad$ EsV-1 and the related Feldmania irregularis virus (FirrV-1) have been sequenced (Delaroque

7 et al., 2001; Delaroque et al., 2003). EsV-1 contains approximately 231 genes with a wide

8 range of predicted functions including DNA metabolism, signalling, transposition, DNA

9 integration and polysaccharide metabolism (Delaroque et al., 2000a,b; Delaroque et al.,

10 2003). It has also been proposed that the ability of the virus to integrate into its host's genome

11 could be exploited to develop a transformation vector for a wide range of brown algae,

12 including E. siliculosus (Henry \& Meints, 1994, Delaroque et al., 1999). However, the

13 complex integration pattern of the virus into the algal genome will considerably complicate

14 this task (N. Delaroque, pers. comm.). A microarray has been constructed to analyse Es V-1

15 gene expression (Declan Schroeder, pers. comm.) and it will be particularly interesting in the

16 future to couple the analysis of viral and genome-wide host gene expression during viral

17 infection.

18 The development of genomic tools provides a new context to investigate the possible 19 genetic basis of the co-evolution between some pathogens and brown algae. The search for 20 inducers of defense responses and resistance against parasites is also still opened as, in 21 contrary with kelps, Ectocarpus does not react with an oxidative burst upon recognition of 22 alginate fragments (Küpper et al., 2002a). 
1 E. siliculosus is able to exploit a wide range of habitats and environmental conditions (see 2 the "Distribution" section). This feature seems likely to be based at least as much as on a high 3 intrinsic genetic variability as on a general physiological toughness, as illustrated by work 4 carried out on copper and saline stress responses.

Interspecific variations in copper tolerance have been observed between different

6 strains of E. fasciculatus and E. siliculosus, with the latter being the most tolerant (Morris, 7 1974). Differences have also been observed among E. siliculosus strains that are differently 8 exposed to copper in their natural habitat (Russell \& Morris, 1970; Hall, 1981). $\mathrm{Cu}^{2+}$ 9 interferes with the general process of photosynthesis in brown algae, and particularly in $E$. siliculosus, by competing with magnesium for metal binding sites in the chlorophyll 11 molecules (Küpper et al., 2002b). A study of the mechanism of tolerance to copper and other heavy metals suggested a co-tolerance to copper, cobalt and zinc, and provided evidence for an exclusion mechanism to explain the particularly low sensitivity of E. siliculosus copper tolerant strains (Hall et al., 1979; Hall, 1980, 1981). However, as yet there is no clear explanation for the intra-specific variation with respect to this trait within this species. develop bioassays in which this alga is used for monitoring marine antifouling characteristics of copper-based materials (Hall and Baker, 1985, 1986). In addition, copper chloride was used to inhibit E. siliculosus infestations in tank cultures of Gracilaria gracilis (Van Heerden et al., 1997).

Russell and Bolton (1975) reported the occurrence of salinity ecotypes within E. siliculosus. This study was extended by Thomas and Kirst (1991a,b) who showed that large differences in photosynthesis, accumulation of osmotically active compounds (mannitol; Davis et al., 2003) and vitality occur between E. siliculosus isolates from different geographic locations 
1 following changes in salinity. They also observed that sporophytes were more salt tolerant

2 than gametophytes, irrespective of their level of ploidy.

3 Detailed investigations are necessary to decipher the physiological and cellular bases of salt

4 and heavy metal tolerance in E. siliculosus. Mutagenesis and transcriptomic approaches will

5 thus help to better understand the mechanisms involved in osmotic and oxidative adaptation, 6 and to explain how these algae can cope with such a wide range of environmental conditions.

7

8

\section{VI- Conclusion}

Taken together, the above sections illustrate the broad range of phenomena that have been studied in Ectocarpus and provide an indication of the domains that could be further explored in the future. Notably, a large proportion of this past work, covering many diverse aspects of Ectocarpus biology, was carried out in Dieter Müller's laboratory in Konstanz, and the efforts of this group have therefore laid the foundations for the development of Ectocarpus as a model organism.

The Ectocarpus genome project has federated a consortium of laboratories with an interest in this organism and these laboratories are currently developing several molecular tools. These include mutant screens, genetic transformation and genome-scale analysis of gene expression. Several developmental mutants have been isolated and positional cloning of some of the affected genes should be feasible in the near future. The availability of the genome sequence together with the ability to analyse gene function by forward and reverse genetic approaches will make it possible to address additional questions, many of which have been evoked in this review. Examples include the biosynthesis of diverse, brown-algal-specific metabolites, such as lipids and complex cell wall components, and the genetic basis of 
1 resistance to biotic and abiotic aggression. The genome will also be an invaluable aide for the

2 study of the ecology of Ectocarpus, by serving as the base for the development of neutral and

3 selected molecular markers for the analysis of field isolates. In conclusion, the Ectocarpus

4 genome sequence and the tool development associated with this project are providing access

5 to a relatively unexplored branch of the eukaryotic tree and some exciting discoveries can be

6 expected in this domain in the coming years.

7

8

9

\section{References}

Alberte RS, Friedman AL, Gustafson DL, Rudnick MS, Lyman H. 1981. Light-harvesting systems of brown algae and diatoms. Isolation and characterization of chlorophyll a/c and chlorophyll a/fucoxanthin pigment-protein complexes. Biochimica et Biophysica Acta 635: 304-316.

Andrews JA. 1976. The pathology of marine algae. Biological Reviews 51: 211-253.

Baker JRJ, Evans LV. 1973a. The ship fouling alga Ectocarpus. I. Ultrastructure and cytochemistry of plurilocular reproductive stages. Protoplasma 77: 1-13.

Baker JRJ, Evans LV. 1973b. The ship fouling alga Ectocarpus. II. Ultrastructure of unilocular reproductive stages. Protoplasma 77: 181-189.

Baldauf SL. 2003. The deep roots of eukaryotes. Science 300: 1703 - 1706.

Barrett J, Anderson JM. 1980. The P-700-chlorophyl alpha-protein complex and two major light-harvesting complexes of Acrocarpia paniculata and other brown seaweeds. Biochimica et Biophysica Acta 590: 309-323.

Beer S. 1994. Mechanisms of inorganic carbon acquisition in marine macroalgae. Progress in Phycological Research 10: 179-207. 
1 Berthold G. 1881. Die geschlechtliche Fortpflanzung der eigentlichen Phaeosporeen. Mitteilungen aus der Zoologischen Station zu Neapel 2: 401-413.

Boalch GT. 1961. Studies on Ectocarpus in culture. Journal of the Marine Biological Association. 41: 279-304.

Boland W, Marner FJ, Jaenicke L. 1983. Comparative receptor study in gamete chemotaxis of the seaweeds Ectocarpus siliculosus and Cutleria multifida - An approach to interspecific communication of algal gametes. European Journal of Biochemistry 134: 97 103.

Boland W, König WA, Krebber R, Müller DG. 1989. Separation of enantiomeric algal pheromones and related hydrocarbons by gas-liquid chromatography on modified cyclodextrins as chiral stationary phases. Biosynthetic relevance of racemic by-products. Helvetica Chimica Acta 72: 1288-1292.

Boland W, Pohnert G, Maier I. 1995. Biosynthesis of algae pheromones. 4. Pericyclicreaction in nature - Spontaneous cope rearrangement inactivates algae pheromones. Angewandte Chemie 34: 1602-1604.

Bolton JJ. 1983. Ecoclinal variation in Ectocarpus siliculosus (Phaeophyceae) with respect to temperature growth optima and survival limits. Marine Biology 73: 131-138.

Bouck GB. 1965. Fine structure and organelle associations in brown algae. Journal of Cell Biology 26: 523-537.

Bräutigam M, Klein M, Knippers R, Müller DG. 1995. Inheritance and meiotic elimination of a virus genome in the host Ectocarpus siliculosus (Phaeophyceae). Journal of Phycology 31: 823-827.

Busch S, Schmid R. 2001. Enzymes associated with $\beta$-carboxylation in Ectocarpus siliculosus (Phaeophyceae): are they involved in net carbon acquisition? European Journal of Phycology 36, 61-70. 
1 Cardinal A. 1964. Étude sur les Ectocarpacées de la Manche. Nova Hedwigia 15: 1-86.

2 Carpita N, McCann M. 2000. The cell wall. In: Buchanan B, Gruissem W, Jones R, eds. Biochemistry and molecular biology of plants. 52-108.

Cho, GY, Lee SH, Boo SM. 2004. A new brown algal order, Ishigeales (Phaeophyceae), established on the basis of plastid protein-coding $\mathrm{rbcL}$, psaA, and psbA region comparisons. Journal of Phycology 40: 921-936. Journal of Cell Science. $118: 2723-2734$.

Craigie JS. 1974. Storage products. In: Stewart WPD, eds. Algal Physiology and Biochemistry. Berkeley, University of California press, USA 206-235.

Davis TA, Volesky B, Mucci A. 2003. A review of the biochemistry of heavy metal biosorption by brown algae. Water research 37: 4311-4330.

Davis, RH. 2004. The age of model organisms. Nature Reviews Genetics 5: 69-75.

Del Campo E, Ramazanov Z, Garcia-Reina G, Müller DG. 1997. Photosynthetic responses and growth performance of virus-infected and noninfected Ectocarpus siliculosus (Phaeophyceae). Phycologia 36: 186-189.

Delaroque N, Maier I, Knippers R, Müller DG. 1999. Persistent virus integration into the genome of its algal host, Ectocarpus siliculosus (Phaeophyceae). Journal of General Virology 80: 1367-1370.

Delaroque N, Wolf S, Müller DG, Knippers R. 2000a. The brown algal virus EsV-1 particle contains a putative hybrid histidine kinase. Virology 273: 383-390.

Delaroque N, Wolf S, Müller DG, Knippers R. 2000b. Characterization and immunolocalization of major structural proteins in the brown algal virus EsV-1. Virology 269: 148-155. 
1 Delaroque N, Müller DG, Bothe G, Pohl T, Knippers R, Boland W. 2001. The complete DNA sequence of the Ectocarpus siliculosus Virus EsV-1 genome. Virology 287: 112132.

Delaroque N, Boland W, Müller DG, Knippers R. 2003. Comparisons of two large phaeoviral genomes and evolutionary implications. Journal of Molecular Evolution 57: 613-622.

De Martino A, Douady D, Quinet-Szely M, Rousseau B, Crépineau F, Apt K, Caron L. 2000. The light-harvesting antenna of brown algae: highly homologous proteins encoded by a multigene family. European Journal of Biochemistry 267: 5540-5549.

Demmig-Adams B, Adams III WW. 1992. Photoprotection and other responses to high light stress. Annual Review of Plant Physiology and Plant Molecular Biology 43: 599-626.

Dixon NM, Leadbeater BSC, Wood KR. 2000. Frequency of viral infection in a field population of Ectocarpus fasciculatus (Ectocarpales, Phaeophyceae). Phycologia 39: 258263.

Draisma SGA, Peters AF, Fletcher RL. 2003. Evolution and taxonomy in the Phaeophyceae: effects of the molecular age on brown algal systematics. In: Norton TA, eds Out of the Past. Collected reviews to celebrate the jubilee of the British Phycological Society. The British Phycological Society, Belfast 87-102.

Eichenberger W, Araki S, Müller DG. 1993. Betaine lipid and phospholipids in brown algae. Phytochemistry 34: 1323-1333.

Evans LV. 1966. Distribution of pyrenoids among some brown algae. Journal of Cell Science 1: 449-454.

Gachon CMM, Küpper H, Küpper FC, Šetlík I. 2006. Witnessing effects of a pathogen on photosynthesis of its host at the cellular level: chlorophyll fluorescence kinetic 
1 microscopy of Pylaiella littoralis (Phaeophyceae) infected by Chytridium polysiphoniae

2 (Chytridiomycota). European Journal of Phycology 41: 395-403.

3 Gachon CM, Day JG, Campbell CN, Proschold T, Saxon RJ, Küpper FC. 2007a. Culture

4 Collection of Algae and Protozoa (CCAP): A biological resource for protistan genomics. Gene. In Press.

Geller A, Müller DG. 1981. Analysis of the flagellar beat pattern of male Ectocarpus siliculosus gametes (Phaeophyta) in relation to chemotactic stimulation by female cells. Journal of Experimental Biology 92: 53-666.

Geissler U. 1983. Die salzbelastete Flußstrecke der Werra - ein Binnenlandstandort für

Grossman AR, Bhaya D, Apt KE, Kehoe DM. 1995. Light-harvesting complexes in oxygenic photosynthesis: diversity, control, and evolution. Annual Review of Genetics 29: 231-288.

Hall A, Fielding AH, Butler M. 1979. Mechanism of copper tolerance in the marine fouling alga Ectocarpus siliculosus - evidence for an exclusion mechanism. Marine Biology 54: 195-199.

Hall A. 1980: Heavy-metal co-tolerance in a copper-tolerant population of the marine fouling alga, Ectocarpus siliculosus (DILLW) LYNGBYE. New Phytologist 85: 73-78.

Hall A. 1981. Copper accumulation in copper-tolerant and non-tolerant populations of the marine fouling alga Ectocarpus siliculosus (Dillw.) Lyngbye. Botanica Marina 24: 223228.

Hall A, Baker AJM. 1985: Settlement and growth of copper-tolerant Ectocarpus siliculosus (DILLW.) LYNGBYE on different copper-based antifouling surfaces under laboratory 
1 conditions.1. Corrosion trials in seawater and development of an algal culture system. 2 Journal of Materials Science 20: 1111-1118.

3 Hall A, Baker AJM. 1986: Settlement and growth of copper-tolerant Ectocarpus siliculosus (DILLW.) LYNGBYE on different copper-based antifouling surfaces under laboratory conditions. 2. A comparison of the early stages of fouling using light and electron microscopy. Journal of Materials Science 21: 1240-1252.

Hartmann M. 1934. Untersuchungen über die Sexualität von Ectocarpus siliculosus. Archiv für Protistenkunde 83: 110-163.

Henry EC, Meints RH. 1994. Recombinant viruses as transformation vectors of marine macroalgae. Journal of Applied Phycology 6: 247-253.

Hillrichs S, Schmid R. 2001. Activation by blue light of inorganic carbon acquisition for photosynthesis in Ectocarpus siliculosus: organic acid pools and short-term carbon fixation. European Journal of Phycology 36: 71-79.

Johnson TW. 1957. Resting spore development in the marine phycomycete Anisolpidium ectocarpii. American Journal of Botany 44: 875-878.

Karling JS. 1943. The life history of Anisolpidium ectocarpii gen. nov. et sp. nov., and a synopsis and classification of other fungi with anteriorly uniflagellate zoospores.

Karling JS. 1944. Phagomyxa algarum n. gen.n. sp., an unusual parasite with plasmodiophoralean and proeomyxean characteristics. American Journal of Botany 31: 38-52.

Katsaros C, Kreimer G, Melkonian M. 1991. Localization of tubulin and a centrinhomologue in vegetative cells and developing gametangia of Ectocarpus siliculosus (Dillw.) Lyngb. (Phaeophyceae, Ectocarpales). Botanica Acta 104: 87-92. 
1 Kawai H. 1988. A flavin-like autofluorescent substance in the posterior flagellum of golden 2 and brown algae. Journal of Phycology 24: 114-117.

3 Kawai H, Müller DG, Fölster E, Häder DP. 1990. Phototactic responses in the gametes of the brown alga, Ectocarpus siliculosus. Planta 182: 292-297.

Kawai H. 1992. A summary of the morphology of chloroplast and flagellated cells in the Phaeophyceae. Korean Journal of Phycology 7: 33-43.

Kawai H, Hanyuda T, Draisma SGA, Müller DG. 2007. Molecular phylogeny of Discosporangium mesarthrocarpum (Phaeophyceae) with a reinstatement of the order Discosporangiales. Journal of Phycology 43: 186-194.

Kim HS, Lee IK. 1992. Morphotaxonomic studies on the Korean Ectocarpaceae (Phaeotphyta) I. Genus Ectocarpus Lyngbye. Korean Journal of Phycology 7(2): 225-242.

Klarzynski O, Plesse B, Joubert J-M, Yvin J-C, Kopp M, Kloareg B, Fritig B. 2000. Linear $\beta-1,3$ glucans are elicitors of defense responses in tobacco. Plant Physiology 124: 1027-1037.

Klein M, Lanka STJ, Müller DG, Knippers R. 1994. Single-stranded regions in the genome of the Ectocarpus siliculosus virus. Virology 202: 1076-1078.

Klenell M, Snoeijs P, Pedersén M. 2002. The involvement of a plasma membrane $\mathrm{H}^{+}-$ ATPase in the blue-light enhancement of photosynthesis in Laminaria digitata (Phaeophyta). Journal of Phycology 38: 1143-1149.

Kloareg B, Quatrano RS. 1988. Structure of the cell walls of marine algae and ecophysiological functions of the matrix polysaccharides. Oceanography and Marine Biology. An Annual Review. 26: 259-315.

Knight M. 1929. Studies in the Ectocarpaceae. II. The life-history and cytology of Ectocarpus siliculosus, Dillw. Transactions of the Royal Society of Edinburgh 56: 307332, 6 plates. 
1 Kornmann P. 1956. Über die Entwicklung einer Ectocarpus confervoides-Form. $2 \quad$ Pubblicazioni della stazione zoologica di Napoli 28: 32-43.

3 Kornmann P, Sahling PH. 1977. Meeresalgen von Helgoland. Benthische Grün-, Braunund Rotalgen. Helgoländer wissenschaftliche Meeresuntersuchungen 29: 1-289.

Kreimer G, Kawai H, Müller DG, Melkonian M. 1991. Reflective properties of the stigma in male gametes of Ectocarpus siliculosus (Phaeophyceae) studied by confocal laser scanning microscopy. Journal of Phycology 27: 268-276.

Kuhlenkamp R, Müller DG. 1994. Isolation and regeneration of protoplasts from healthy and virus-infected gametophytes of Ectocarpus siliculosus (Phaeophyceae). Botanica Marina 37: 525-530.

Küpper FC, Müller DG. 1999. Massive occurrence of the heterokont and fungal parasites Anisolpidium, Eurychasma and Chytridium in Pylaiella littoralis (Ectocarpales, Phaeophyceae). Nova Hedwigia 69: 381-389.

Küpper FC, Müller D, Peters A, Kloareg B, Potin P. 2002a. Oligoalginate recognition and oxidative burst play a key role in natural and induced resistance of sporophytes of Laminariales. Journal of Chemical Ecology 28: 2057-2081.

Küpper H, Šetlík I, Spiller M, Küpper FC, Prášil O. 2002b. Heavy metal-induced inhibition of photosynthesis: Targets of in vivo heavy metal chlorophyll formation. Journal of Phycology 38: 429-441.

Küpper FC, Maier I, Müller DG, Loiseaux-de Goër S, Guillou L. 2006. Phylogenetic affinities of two eukaryotic pathogens of marine macroalgae, Eurychasma dicksonii and Chytridium polysiphoniae. Cryptogamie Algologie 27: 165-184.

Le Gall Y, Brown S, Marie D, Mejjad M, Kloareg B. 1993. Quantification of nuclear DNA and G-C content in marine macroalgae by flow cytometry of isolated nuclei. Protoplasma 173: $123-132$. 
1 Lanka STJ., Klein M, Ramsperger U, Müller DG, Knippers R. 1993. Genome structure of

2 a virus infecting the marine brown alga Ectocarpus siliculosus. Virology 193: 802-811.

3 Lemoine Y, Harker M, Rmiki NE, Rousseau B, Berkaloff C, Duval JC, Young AJ, Britton G. 1995. Xanthophyll cycle operation and photoprotection in brown algae: effects of high light and desiccation. In Photosynthesis, from Light to Biosphere (Mathis, P., ed.), vol. IV, 119-122. Kluwer, Dordrecht.

Lofthouse PF , Capon B. 1975. Ultrastructural changes accompanying mitosporogenesis in Ectocarpus parvus. Protoplasma 84: 83-99.

Maier I, Schmid CE. 1995. An immunofluorescence study on lectin binding sites in gametes of Ectocarpus siliculosus (Ectocarpales, Phaeophyceae). Phycological Research 43: 33-

Maier I. 1997a. The fine structure of the male gamete of Ectocarpus siliculosus (Ectocarpales, Phaeophyceae). I. General structure of the cell. European Journal of Phycology 32: 241-253.

Maier I. 1997b. The fine structure of the male gamete of Ectocarpus siliculosus (Ectocarpales, Phaeophyceae). II. The flagellar apparatus. European Journal of Phycology 32: 255-266.

Maier I, Müller DG. 1998. Virus binding to brown algal spores and gametes visualized by DAPI fluorescence microscopy. Phycologia 37: 60-63.

Maier I, Parodi E, Westermeier R, Müller DG. 2000. Maullina ectocarpii gen. et sp. nov. (Plasmodiophorea), an intracellular parasite in Ectocarpus siliculosus (Ectocarpales, Phaeophyceae) and other filamentous brown algae. Protist 151: 225-238.

McHugh DJ. 2003. A guide to the seaweed industry. FAO Fisheries Technical Paper No. 441. FAO, Rome: 105 pp. 
1 Moreira D, Le Guyader H, Philippe H. 2000. The origin of red algae and the evolution of 2 chloroplasts. Nature 405: 69-72.

3 Morris OP. 1974. Inter-specific differences in responses to copper by natural populations of Ectocarpus. British Phycology Journal 9: 269-272.

Morris OP, Russel G. 1974. Inter-specific differences in responses to copper by natural populations of Ectocarpus. British Phycology Journal 9: 269-272.

Müller DG. 1963. Die Temperaturabhängigkeit der Sporangienbildung bei Ectocarpus Napoli 33: 310-314.

Müller DG. 1964. Life-cycle of Ectocarpus siliculosus from Naples, Italy. Nature 26: 1402.

Müller DG. 1966. Untersuchungen zur Entwicklungsgeschichte der Braunalge Ectocarpus siliculosus aus Neapel. Planta 68: 57-68.

Müller DG. 1967. Generationswechsel, Kernphasenwechsel und Sexualität der Braunalge

Müller DG. 1972b. Studies on reproduction in Ectocarpus siliculosus. Société Botanique

Müller DG, Falk H. 1973. Flagellar structure of the gametes of Ectocarpus siliculosus (Phaeophyta) as revealed by negative staining. Archiv für Mikrobiologie 91: 313-322.

Müller DG. 1976a. Sexual isolation between a European and an American population of Ectocarpus siliculosus (Phaeophyta). Journal of Phycology 12: 252-254. 
1 Müller DG. 1976b. Quantitative evaluation of sexual chemotaxis in two marine brown algae.

2 Zeitschrift für Planzenphysiologie 80: 120-130.

3 Müller DG. 1978. Locomotive responses of male gametes to the species specific sex attractant in Ectocarpus siliculosus (Phaeophyta). Archiv für Protistenkunde 120: 371377.

Müller DG. 1980. Entwicklung von Ectocarpus siliculosus (Phaeophyta). Film C 1308 des IWF, Göttingen 1979. Publikationen zu wissenschaftlichen Filmen, Sektion Biologie, Serie 13 11/C 1308: 1-15.

Müller DG, Maier I, Müller H. 1987. Flagellum autofluorescence and photoaccumulation in

Müller DG, Schmid CE. 1988. Qualitative and quantitative determination of pheromone 
1 Müller DG, Eichenberger W. 1995. Crossing experiments, lipid composition, and the species concept in Ectocarpus siliculosus and E. fasciculatus (Phaeophyceae, Ectocarpales). Journal of Phycology 31: 173-176.

Müller DG. 1996. Host-virus interactions in marine brown algae. Hydrobiologia 327: 21-28.

Müller DG, Schmid CE. 1996. Intergeneric infection and persistence of Ectocarpus virus DNA in Kuckuckia (Phaeophyceae, Ectocarpales). Botanica Marina 39: 401-405.

Müller DG, Sengco M, Bräutigam M, Schmid CE, Kapp M, Knippers R. 1996. Comparison of two DNA viruses infecting the marine brown algae Ectocarpus siliculosus and E. fasciculatus. Journal of General Virology 77: 2329-2333.

Müller DG, Eichenberger W. 1997. Mendelian genetics in brown algae: inheritance of a lipid defect mutation and sex alleles in Ectocarpus siliculosus (Ectocarpales, Phaeophyceae). Phycologia 36: 79-81.

Müller DG, Kapp M, Knippers R. 1998. Viruses in marine brown algae. Advances in Virus Research 50: 50-67.

Müller DG, Küpper FC, Küpper H. 1999. Infection experiments reveal broad host ranges of Eurychasma dicksonii (Oomycota) and Chytridium polysiphoniae (Chytridiomycota), two eukaryotic parasites in marine brown algae (Phaeophyceae). Phycological Research $47: 217-223$

Müller DG, Westermeier R, Morales J, Garcia Reina G, Del Campo E, Correa JA, Rometsch E. 2000. Massive prevalence of viral DNA in Ectocarpus (Phaeophyceae, Ectocarpales) from two habitats in the North Atlantic and South Pacific. Botanica Marina 43: 157-159.

Müller DG, Knippers R. 2001. Phaeovirus, Phycodnaviridae. In: Tidona CA, Darai G, eds. The Springer Index of Viruses. Springer, Berlin, Heidelberg, New York, 732-736. 
1 Oliveira L, Bisalputra T. 1973. Studies in the brown alga Ectocarpus in culture. Journal of $2 \quad$ Submicrobial Cytology 5: 107-120.

3 Oliveira L, Bisalputra T. 1977a. Ultrastructural studies in the brown alga Ectocarpus in culture: autolysis. New Phytologist 78: 139-145.

Oliveira L, Bisalputra T. 1977b. Ultrastructural studies in the brown alga Ectocarpus in culture: ageing. New Phytologist 78: 131-138.

Oltmanns F. 1899. Ueber die Sexualität der Ectocarpeen. Flora 86: 86-99.

Papenfuss GF. 1935. Alternation of generations in Ectocarpus siliculosus. Botanical Gazette 96: 421-446.

Pedersén M. 1968. Ectocarpus fasciculatus: marine brown alga requiring kinetin. Nature 218: 776.

Pedersén M. 1973. Identification of a cytokinin, 6-(3 methyl-2-butenylamino) purine, in sea

Pedersén PM. 1989. Studies on Kuckuckia spinosa (Fucophyceae, Sorocarpaceae): life history, temperature gradient experiments, and synonymy. Nordic Journal of Botany 9: 443-447.

Peters AF, Marie D, Scornet D, Kloareg B, Cock JM. 2004a. Proposal of Ectocarpus siliculosus (Ectocarpales, Phaeophyceae) as a model organism for brown algal genetics and genomics. Journal of Phycology 50: 1079-1088.

Peters AF, Scornet D, Müller DG, Kloareg B, Cock JM. 2004b. Inheritance of organelles in artificial hybrids of the isogamous multicellular chromist alga Ectocarpus siliculosus (Phaeophyceae). European Journal of Phycology 39: 235-242.

Petersen HE. 1905. Contributions à la connaissance des phycomycètes marins (Chytridinae Fischer). Oversigt over det kgl. Danske Videnskabernes Selskats Forhandlinger 5: 439488. 
1 Rattray J. 1885. Note on Ectocarpus. Transactions of the Royal Society of Edinburgh 32: $589-602$.

Ravanko O. 1970. Morphological, developmental, and taxonomic studies in the Ectocarpus complex (Phaeophyceae). Nova Hedwigia 20: 79-252.

Robledo DR, Sosa PA, Garcia-Reina G, Müller DG. 1994. Photosynthetic performance of healthy and virus-infected Feldmannia irregularis and F. simplex (Phaeophyceae). European Journal of Phycology 29: 247-251.

Rousseau F, de Reviers B. 1999. Circumscription of the order Ectocarpales (Phaeophyceae): bibliographical synthesis and molecular evidence. Cryptogamie, Algologie 20: 5-18.

Russell G. 1966. The genus Ectocarpus in Britain. I. The attached forms. Journal of the marine biological Association of the United Kingdom 46: 267-294.

Russell G. 1967a. The genus Ectocarpus in Britain. II. The free-living forms. Journal of the marine biological Association of the United Kingdom 47: 233-250.

Russell G. 1967b. The ecology of some free-living Ectocarpaceae. Helgoländer wissenschaftliche Meeresuntersuchungen 15: 155-162.

Russell G, Morris OP. 1970. Copper tolerance in the marine fouling alga Ectocarpus siliculosus. Nature 228: 288-289.

Russell G, and Bolton JJ. 1975. Euryhaline ecotypes of Ectocarpus siliculosus (Dillw.) Lyngb. Estuarine and Coastal Marine Science 3: 91-94.

Russell G. 1983a. Parallel growth patterns in algal epiphytes and Laminaria blades. Marine Ecology Progress Series 13: 303-304.

Russell G. 1983b. Formation of an ectocarpoid epiflora on blades of Laminaria digitata. Marine Ecology Progress Series 11: 181-187.

Sauvageau C. 1896. Sur la conjugaison des zoospores de l'Ectocarpus siliculosus. Comptes rendus de l'Académie des Sciences 123: 431-433. 
1 Sauvageau C. 1897. La copulation isogamique de l'Ectocarpus siliculosus est-elle apparente ou réelle ? Mémoires de la Société nationale des sciences naturelles de Cherbourg 30: 293-304.

Schmid R, Dring MJ. 1992. Circadian rhythm and fast responses to blue light of photosynthesis in Ectocarpus (Phaeophyta, Ectocarpales). Planta 187: 53-59.

Schmid CE, Schroer N, Kawai H, Müller DG. 1992. Isolation and biochemical characterization of different gamete membranes in the chromophyte alga Ectocarpus siliculosus (Phaeophyceae). Plant Physiology and Biochemistry 30: 703-712.

Schmid CE. 1993. Cell-cell-recognition during fertilization in Ectocarpus siliculosus (Phaeophyceae). Hydrobiologia 260-261: 437-443.

Schmid R, Dring MJ. 1993. Rapid, blue-light-induced acidifications at the surface of Ectocarpus and other marine macroalgae. Plant Physiology 101: 907-913.

Schmid CE, Schroer N, Müller DG. 1994a. Female gamete membrane glycoproteins potentially involved in gamete recognition in Ectocarpus siliculosus (Phaeophyceae). Plant Science 102: 61-67.

Schmid R, Dring MJ, Forster RM. 1994b. Kinetics of blue light stimulation and circadian rhythmicity of light-saturated photosynthesis in brown algae: a species comparison. Journal of Phycology 30: 612-621.

Schmid CE, Müller DG, Eichenberger W. 1994c. Isolation and characterization of a new phospholipid from brown algae. Intracellular localization and site of biosynthesis. Journal of Plant Physiology 143: 570-574.

Schmid R, Dring MJ. 1996. Influence of carbon supply on the circadian rhythmicity of photosynthesis and its stimulation by blue light in Ectocarpus siliculosus: clues to the mechanism of inorganic carbon acquisition in lower brown algae. Plant, Cell and Environment 19: 373-382. 
1 Schmid R. 1998. Photosynthesis of Ectocarpus siliculosus in red light and after pulses of blue

2 light at high $\mathrm{pH}$ - evidence for bicarbonate uptake. Plant, Cell and Environment 21: 5233529.

Schmid R, Hillrichs S. 2001. Uptake and accumulation of inorganic carbon in Ectocarpus siliculosus and its relation to blue light stimulation of photosynthesis. European Journal of Phycology 36: 257-264.

Sengco M, Bräutigam M, Kapp M, Müller DG. 1996. Detection of virus DNA in Ectocarpus siliculosus and E. fasciculatus (Phaeophyceae) from various geographic areas. European Journal of Phycology 31: 73-78.

Silva PC, Basson P, Moe RL. 1996. Catalogue of the benthic marine algae of the Indian Ocean. University of California Publications in Botany 79: 1-1259.

Stache, B. 1990. Sexual compatibility and species concept in Ectocarpus siliculosus (Ectocarpales, Phaeophyceae) from Italy, North Carolina, Chile, and New Zealand. In: Garbary, D. J. \& R. G. South (ed). Evolutionary Biogeography of the Marine Algae of the North Atlantic. Springer Vlg., Berlin: 173-186.

Stache-Crain B, Müller DG, Goff LJ. 1997. Molecular systematics of Ectocarpus and Kuckuckia (Ectocarpales, Phaeophyceae) inferred from phylogenetic analysis of nuclear and plastid-encoded DNA sequences. Journal of Phycology 33: 152-168.

Thomas DN, Kirst GO. 1991a. Salt tolerance of Ectocarpus siliculosus (Dillw.) Lyngb.: comparison of gametophytes, sporophytes and isolates of different geographic origin. Botanica Acta 104: 26-36.

Thomas DN, Kirst GO. 1991b. Differences in osmoacclimation between sporophytes and gametophytes of the brown alga Ectocarpus siliculosus. Physiologia Plantarum 83: 281289. 
1 Van Etten JL, Meints RH. 1999. Giant viruses infecting algae. Annual Review of $2 \quad$ Microbiology 53: 447-494.

3 Van Etten JL, Graves MV, Müller DG, Boland W, Delaroque N. 2002. Phycodnaviridae large DNA algal viruses. Archives of Virology 147: 1479-1516.

Van Heerden PDR, Robertson BL, De Kock L. 1997. Inhibition of Ectocarpus siliculosus

West JA, Kraft GT. 1996. Ectocarpus siliculosus (Dillwyn) Lyngb. from Hopkins River Falls, Victoria - the first record of a freshwater brown alga in Australia. Muelleria 9: 2933.

Wiencke C, Clayton MN. 2002. Antarctic seaweeds. Synopses of the Antarctic benthos, vol. 9. Gantner, Ruggell, Liechtenstein. 159 pp.

Wright EP. 1879. On a species of Rhizophydium parasitic on species of Ectocarpus, with notes on the fructification of the Ectocarpi. Transactions of the Royal Irish Academy 26:

Figure legends:

Figure 1: Phylogeny of brown algae and Ectocarpales.

a: Position of brown algae within the eukaryotes (adapted from Baldauf, 2003). Brown algae belong to the heterokont phylum, which is phylogenetically distant from land plants and the green and red algae. Photosynthetic organisms are framed. b: Position of the Ectocarpales (in bold) within the brown algae (adapted from Kawai et al., 2007). 
1 Figure 2: Life cycle of Ectocarpus siliculosus.

2 Diploid sporophytes produce meio-spores (by meiosis) in unilocular sporangia (UL). Meio3 spores grow into male or female gametophytes (dioecism). Gametophytes produce gametes in

4 plurilocular gametangia (PL). Fusion of gametes produces a zygote that grows into a diploid 5 sporophyte, completing the sexual cycle. Unfused gametes may grow parthenogenetically and 6 form a parthenosporophyte, which is indistinguishable from the diploid sporophyte. Both 7 sporophytes and parthenosporophytes can reproduce themselves asexually by the production of mito-spores in plurilocular sporangia.

Figure 3: Morphology of Ectocarpus siliculosus.

11 Photographies of one week old vegetative sporophyte (a) and gametophyte (b) and schemes representing the whole body of the mature sporophyte (c) and gametophyte (d) after six weeks of growth, are shown. e: Plurilocular sporangium or gametangium (occurring on the sporophyte and the gametophyte, respectively) before (left) and after (right) release of zoids. f: Unilocular sporangium from sporophyte. Sporangia and gametangia can be either sessile or 16 pedicellate (Kim \& Lee, 1992).

Figure 4: General ultrastructure of a vegetative cell of Ectocarpus siliculosus.

The general ultrastructure of a vegetative cell is similar in both prostrate and erect filaments (Oliveira \& Bisalputra, 1973). The different compartments of the cell are illustrated (see text for details). Lines represent membranes and define sub-cellular compartments, except for thylakoids, drawn as a thick black line. Depending on their type and age, vegetative cell size varies from 10 to $35 \mu \mathrm{m}$ in length, and 5 to $15 \mu \mathrm{m}$ in width (in laboratory culture conditions).

Figure 5: General intracellular structure of Ectocarpus siliculosus zoids. 
1 A scheme representing the different compartments of an Ectocarpus siliculosus zoid cell from

2 a plurilocular sporangium or gametangium is presented (see text for details). Legends are the 3 same as in fig. 4.

4

\section{Acknowledgements}

6 We are grateful to N. Delaroque (Max Plank Institute in Jena) for authorisation to 7 communicate unpublished information about viral integration, and to Declan Schroeder 8 (Marine Biological Association in Plymouth) for authorisation to mention the microarray for 9 the EsV-1 virus. 
Figure 1

a

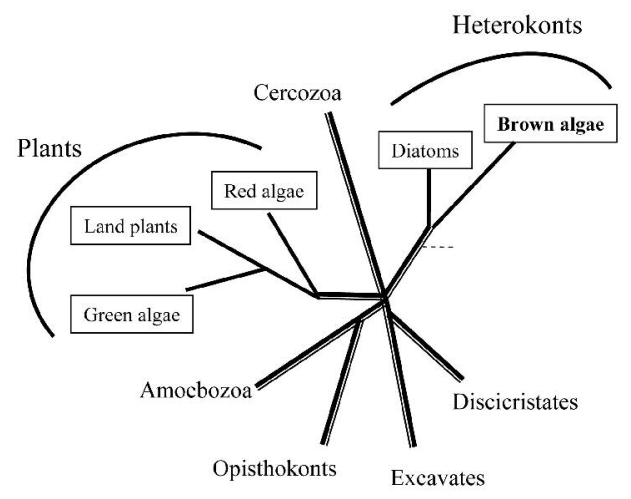

b

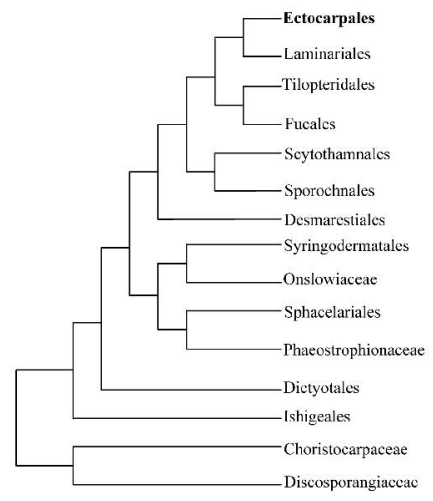

Figure 1: Phylogeny of brown algae and Ectocarpales. a: Position of brown algae within the eukaryotes (adapted from Baldauf, 2003). Brown algae belong to the heterokont phylum, which is phylogenetically distant from land plants and the green and red algae. Photosynthetic organisms are framed. b: Position of the Ectocarpales (in bold) within the brown algae (adapted from Kawai et al., 2007).

$275 \times 190 \mathrm{~mm}(300 \times 300 \mathrm{DPI})$ 


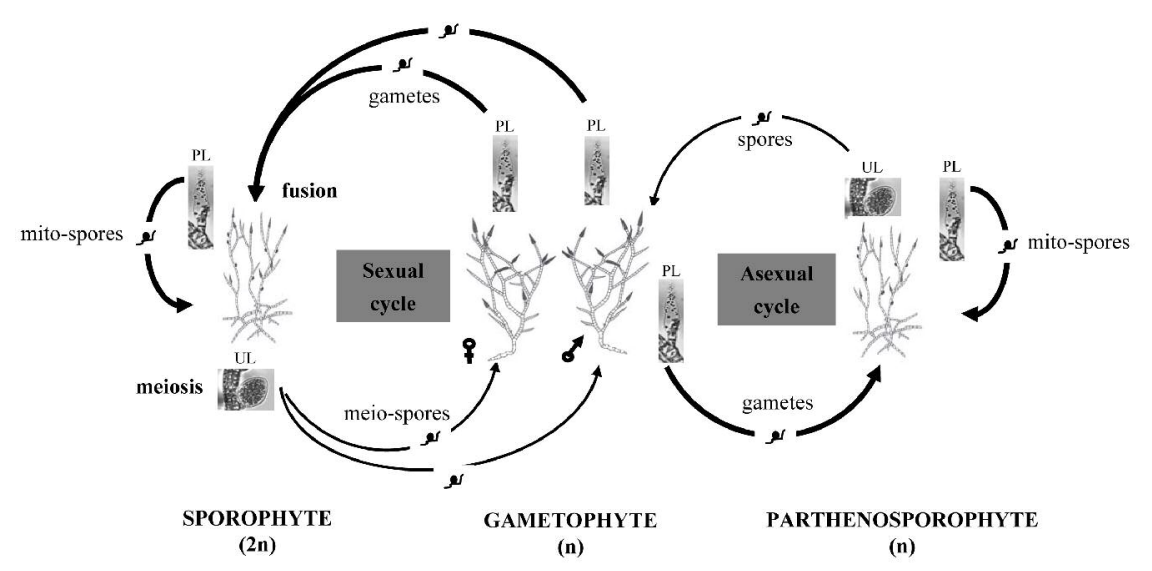

Figure 2: Life cycle of Ectocarpus siliculosus. Diploid sporophytes produce meio-spores (by meiosis) in unilocular sporangia (UL). Meio-spores grow into male or female gametophytes (dioecism). Gametophytes produce gametes in plurilocular gametangia (PL). Fusion of gametes produces a zygote that grows into a diploid sporophyte, completing the sexual cycle. Unfused gametes may grow parthenogenetically and form a parthenosporophyte, which is indistinguishable from the diploid sporophyte. Both sporophytes and parthenosporophytes can reproduce themselves asexually by the production of mito-spores in plurilocular sporangia. $254 \times 190 \mathrm{~mm}(300 \times 300 \mathrm{DPI})$ 
Figure 3

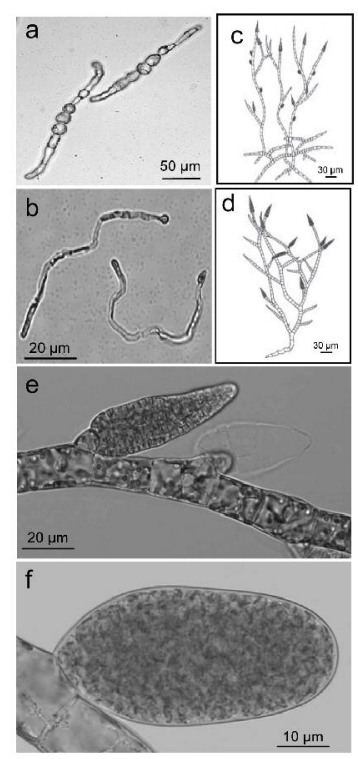

Figure 3: Morphology of Ectocarpus siliculosus. Photographies of one week old vegetative sporophyte (a) and gametophyte (b) and schemes representing the whole body of the mature sporophyte (c) and gametophyte (d) after six weeks of growth, are shown. e: Plurilocular sporangium or gametangium (occurring on the sporophyte and the gametophyte, respectively) before (left) and after (right) release of zoids. f: Unilocular sporangium from sporophyte. Sporangia and gametangia can be either sessile or pedicellate (Kim \& Lee, 1992). $254 \times 190 \mathrm{~mm}(300 \times 300$ DPI $)$ 
Figure 4

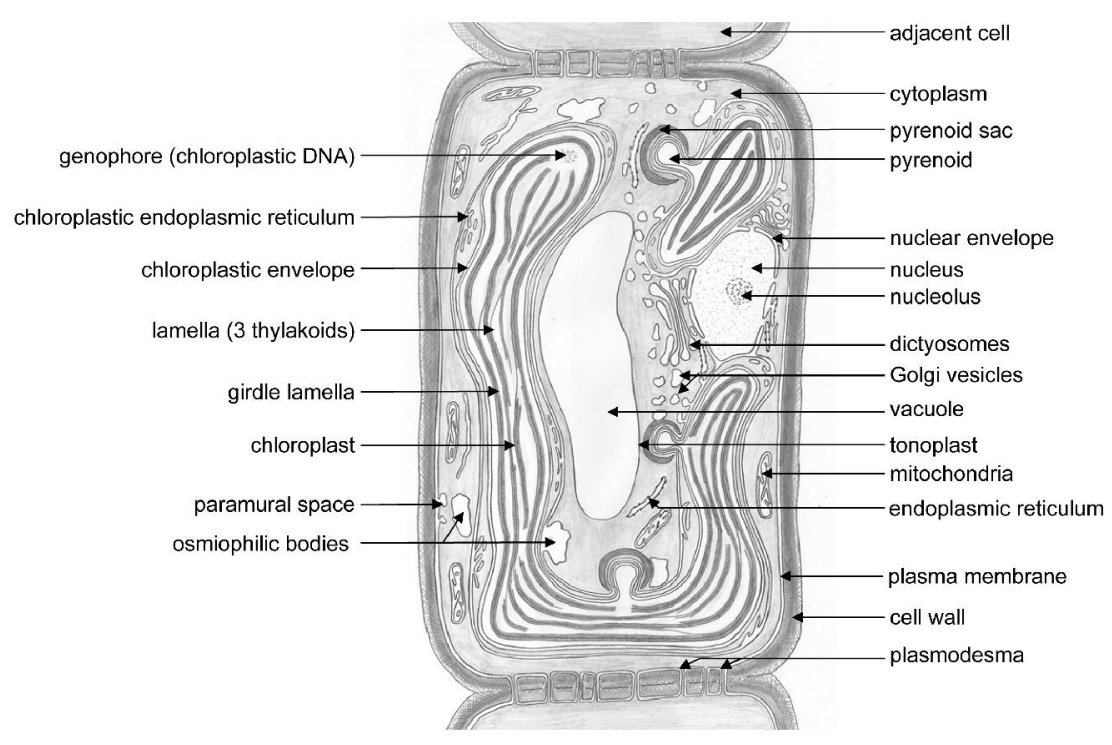

Figure 4: General ultrastructure of a vegetative cell of Ectocarpus siliculosus. The general ultrastructure of a vegetative cell is similar in both prostrate and erect filaments (Oliveira \& Bisalputra, 1973). The different compartments of the cell are illustrated (see text for details). Lines represent membranes and define sub-cellular compartments, except for thylakoids, drawn as a thick black line. Depending on their type and age, vegetative cell size varies from 10 to $35 \mu$ m in length, and 5 to $15 \mu$ m in width (in laboratory culture conditions).

$254 \times 190 \mathrm{~mm}(300 \times 300$ DPI $)$ 


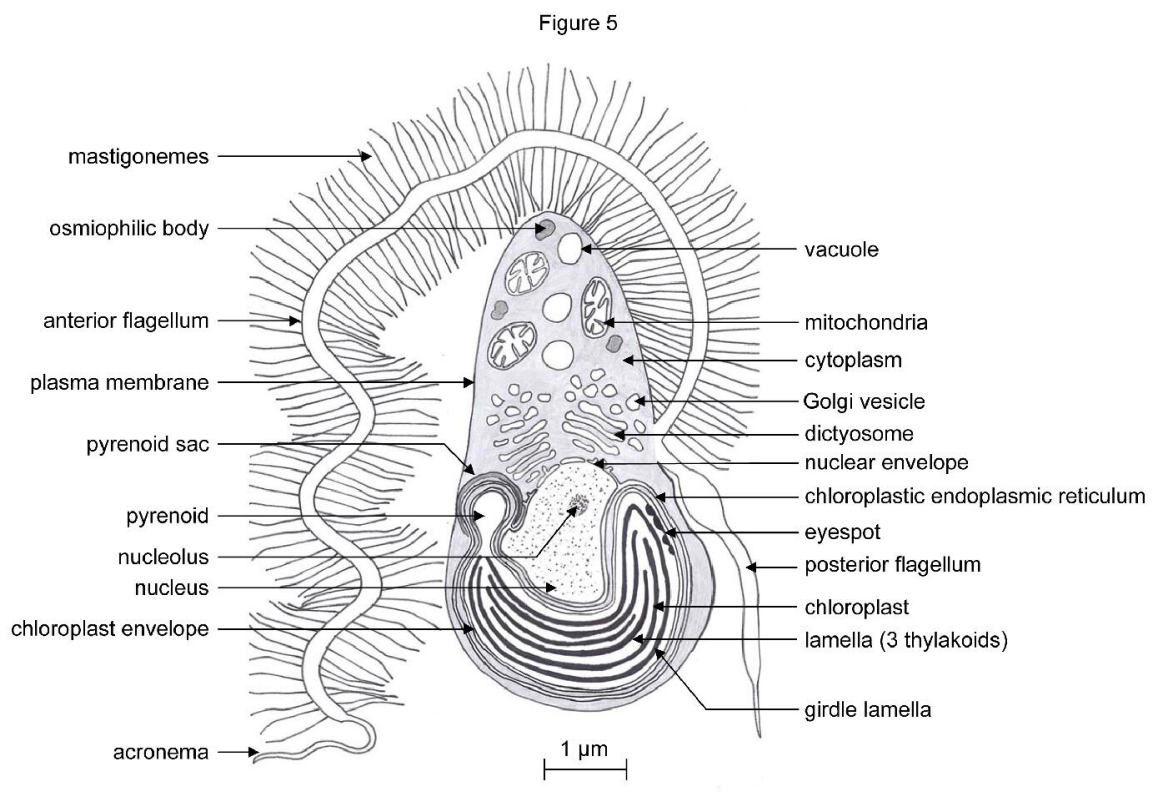

Figure 5: General intracellular structure of Ectocarpus siliculosus zoids. A scheme representing the different compartments of an Ectocarpus siliculosus zoid cell from a plurilocular sporangium or gametangium is presented (see text for details). Legends are the same as in Fig. 4.

$254 \times 190 \mathrm{~mm}(300 \times 300$ DPI $)$ 